beef-tea, \&c., as she best fancied. In spite of all this, the fungus increased to several times its size on almission, the pain became, if possible, worse, and the discharge more profuse, and she again became weaker, and more worn down by the disease.

Under these circumstances, Mr. Solly thought it best to remove the entire diseased mass, not with the hope of curing her, but simply to relieve her from her agony and the profuse, foul discharge, which, soaking her linen, made her miserable and loathsome.

Nov. 14th.--Having obtained the patient's consent, Mr. Solly to-day removed the whole of it, making his incision in the surrounding apparently sound skin, and dissecting it off the pectoralis major, which was, however, clearly infiltrated by cancerous deposit. Hrmorrhage was profuse, and seven or eight arteries were secured. The operation was performed under chloroform, and she was carried to bed in an extremely weak state. One grain of hydrate of morphia to be taken immediately.-Five P. 1r. : After wandering for a little time, from the continued effects of chloroform and morphia, she fell asleep, and awoke refreshed. Her skin is now warm, and her pulse has somewhat rallied. She has vomited since the operation, and she still feels very faint. Wine, one ounce.-Nine P.M.: Circulation restored, and she feels very comfortable. Repeat morphia. Wet lint to wound.

15th. - No pain on the breast or arm; slept well; complains of pain across the epigastrium.

16th. - Pain in the region of the liver, and a tumour can be felt there, very tender, extending across the right hypochondrium to the epigastrium; its lower border is well defined; bowels costive.

17th. -The lint placed on the wound after the operation cannot be removed, as it adheres so firmly to the surface.

$22 \mathrm{nd}$. - Put her under the influence of chloroform, and removed the lint adhering to the surface of the wound, it being found next to impossible to do it without, as the attempt caused her such agony; sleeps well; tumour in the abdomen about the same; bowels open.

24th.-Tumonx in the abdonen larger and more tender, especially in the epigastric region; wound looks very healthy; bowels very costive. To have an enema at night, composed of two ounces of decoction of aloes. To have fish to-morrow morning.

26th.-Bowels well opened; tumour in the epigastrium smaller; liver feels enlarged as before; sleeps well, but is troubled by earache.

28th. - Wounds looks very healthy; complains of more pain in the epigastrium, accompanied by tenderness and soreness of that region; bowels not opened since the discontinuance of the enema ; appetite good. Ropeat decoction of aloes at night.

30th.-Bowels open every day; tumour in the epigastrium smaller, and less uneasiness; wound looks very healthy, beginning to cicatrize.

The progress of this case since the operation up to the present time amply justifies its performance. I am now sorry that I did not operate on her sooner after her admission. I know that the disease is not eradicated, but $I$ hope that it will take an inward course, which is far less distressing to its victim, and the liver seems to be the seat of it. The chloride of bromine has been recommended as a specific in cancer. I have only as yet tried it in two cases, but in neither have I seen any beneficial result. In some cases, I have thought that Dr. Arnott's apparatus has retarded the growth of this disease, and that in open cancer it has rendered the ulcer less offensive. On the whole, I have, however, been disappointed in its effect, and I seldom employ it now in any case.

In the performance of these operations, you must not attempt to save much skin with the idea of getting the wound to heal rapidly with the first intention. When the disease returns externally, it is generally on the skin which forms the edge of the cicatrix, looking as if we might have prevented it if we had taken a little more of the integument. You must also be very careful to dissect the pectoral muscle very cleanly; do not leave any cellular tissue over it. In making your first incision, remember that you make it below the mamma, and then the blood flows away from your knife, so that you see each tissue more distinctly as you expose it. Examine carefully the surface of the wound, in order to satisfy yourself that you have left no palpable piece behind. Also make a section of the tumour This enables you to see if you have removed a circle of healthy cellular tissue beyond its margin.

These cases, in private practice, are the most disagreeable and unsatisfactory that you can have to do with. Of course, your conduct will be guided alone by a strict sense of duty: you will neither be tempted to operate on account of the fee, nor tempted to refuse on account of the discredit which follows in consequence of a return of the disease. You will calmly consider what is on the whole best for your patient, swayed neither by her fears or those of her friends, nor by the prejudices of the practitioner in attendance, if such there be to contend with. It is most important that the patient herself should not know all your fears and all your doubts ; it is most important that one or more judicious friends should know your real opinion. In these melancholy cases the husband is seldom the person who can be trusted. Fortunately for us, as no man living can say positively that the disease must return and must be fatal, we'are justified in giving the sufferer the benefit of the doubt, particularly when hope itself may be the means of prolonging, if not of saving, life.

\section{THE TURKISH HOSPITAL AT BALACLAVA.}

By J. N. RADCLIFFE, EsQ.,

OF THE BRTMSH MEDICAL STAFF ATTACHED TO THE OTTOMAN ARMY.

There is a cluster of wooden huts, situated in an almost central position within the lines, on the heights west of Bala. klava. The huts are twenty-eight in number, and they formed the general hospital of the Ottoman force in and about the Chersonesus, until the removal of that force to Asia Minor. They are placed on a knoll at the head of the ravine which opens out near the centre of Balaklava, and the situation is well adapted for hospital purposes. There is every facility for drainage and cleanliness ; numerous and abundant springs of excellent water are in the vicinity; and the neighbouring heights shelter the huts, in a great measure, from all but north-easterly winds.

The huts are of British construction, and their walls and roofs are built of "half-inch" planks; the roofs have also, with few exceptions, a waterproof felt covering. The large huts, twenty-four in number, are thirty-two feet in length eighteen feet in breadth ; seven feet in height to the pitch, and twelve feet to the apex of the roof. Each of these huts has two windows-one being placed at each extremity. The windows are three feet square; they are elevated seven feet above the floor; and the sashes are glazed and move on a transverse axis. There is a single door to each hut, and it opens in the majority of them to the south-the huts being arranged so that their longitudinal axis is almost directly north and south.

Within each hut is a central pathway, three feet in width, which runs from end to end ; and on each side of this is a wood flooring, raised six inches from the ground, and seven feet and a half in width.

The huts are placed very close together, the intervening spaces not measuring more than six feet; and each hut is trenched round, but in a very imperfect manner, for the trenches are not sufficiently deep, they have no communication with each other, and no outlet on the slope of the hill; and, in consequence, the ground about the huts during rain becomes a mass of soft mud.

The huts have been erected and used as an hospital about nine months. During the hot season the wood warped and cracked considerably, and it became difficult to exclude wind and rain. The huts swarm with rats and mice, the square beneath the flooring giving every shelter to these pests; and the walls, within and without, are neither painted nor whitewashed.

The four smaller huts are of stronger and better construction than the larger ones. They are about ten feet square, and are painted externally. They were occupied by the resident phy. pick and by sick officers.

Each of the large huts accommodated fourteen patients; and to each hut was attached two orderlies, who lived and slept in the hut of which they had charge. No bedsteads were used, the patients being placed on good flock-beds, of about four inches in thickness, which were laid upon the wood floor. These beds were covered with a kind of cotton, which was thick, white and soft; and each bed was provided with a sheet of the same material and a warm white coverlid. Additional covering might be had, if required; but as each patient had his heavy uniform overcoat with him, this was rarely necessary. The beds and bed-linen, and indeed the patient's dress generally, were kept wonderfully clean; and the principal portion of the materials being white, the aspect of the occupied huts was in general neat and satisfactory. The bed furniture 
and clothing of the patients were much more cleanly than their persons ; for the Mussulman soldier, when in the field and out of the way of baths, appears to be very filthy in his person and habits, notwithstanding that he may wash his hands and feet several times during the day, according to the prescribed rules of his religion. Fleas and lice infested the clothing of the patients and the bedding, but not to so great an extent as might have been expected. The hospital dress consisted of a long, blue, wide-sleeved loose coat of coarse material, in addition to the under clothing-wide cotton drawers, and a vest of thick cotton.

Each hut was provided with two large and very useful metal basins for the general use of its occupants, and a sufficient number of small basins, (also of metal,) for food, cups, plates, spoons, sponges, a charcoal burner, \&c. ; and with a tub or a number of bottles for water.

Although much may be said of the comparative cleanliness of the hospital huts within, little can be said of the cleanliness of the patients and authorities external to them.

The latrine for general use was placed about thirty feet from the huts, on the slope of the hill, to the west. It was a wood building, roofed in, and about twenty feet in length, and it contained the accumulated ejections of the patients for six months. To the left of the latrine, at about thirty feet distance, was the cooking-house, and in its rear a hut for stores. In the space between these buildings and the latrine, it was customary, for many months, to kill the oxen and sheep required for the use of the hospital. The whole of the blood from the slain animals was allowed to run, and the refuse was thrown, into a hole behind the store-hut. This hole was dise tant about fifty yards from the hospital huts, and it was full to overflowing of decomposing animal matter, from which arose a stench even worse than that from the latrine.

Notwithstanding the contignity of this sink of abomination, and of the latrine, and that the ground was in a most filthy state, a short time previous to the removal of the Ottoman force, several tents were pitched in the space between the cooking and store-huts and the latrine, and they were occupied by sick officers. Two tent latrines were pitched in the rear of the tents, and close to the walls of the store-hut, for the use of the sick officers.

An important source of atmospheric vitiation, in the immediate neighbourhood of the hospital, arose from an abominable habit which the Turkish soldiers have of avoiding, when practicable, all places set apart for freal ejections. This propensity, which is very unpleasantly evident to the senses in the vicinity of most of their encampments, was allowed too much scope by the hospital anthorities, and, in consequence, the slopes of the knoll on which the huts are situated were polluted in all directions.

The bed-pan in use in the hospital was a two-handled iron vessel, of very inconvenient size and form. This utensil was, however, too rarely had recourse to ; and it was often painful to witness patients, in a case of serious prostration from disease, conducted to the latrine by an orderly.

The food issued to the patients was tolerably good, and in sufficient quantity. The General Diet Table was as follows:

Full Diet: Bread, half an oke (an oke is about two pounds and three-quarters, English weight); rice, ninety-two drachms; butter, eight drachms (used in making pillaff of the rice); meat (beef or mutton), 100 drachms; onions; a kind of bran, termed nohud, or nokhud (if in store), and salt.

Diet for Convalescents: Bread, 100 drachms; rice, eighty drachms; butter, eight drachms; and meat, fifty drachms. The meat was boiled, seasoned with salt and pepper, and served with the broth.

Low Diet: Bread, thirty-three drachms and a half; rice, twenty-seven drachms; and soup, or rather broth, made from mutton or beef, as much as may be required.

Two candles, a certain amount of olive oil (for lamps), soap, and charcoal (and wood when fires were used), were served out for each hut daily.

The military officer in charge (a Bey) had power to provide whatever the physicians and surgeons in attendance might order, in addition to the ordinary dietary, spirituous liquors alone being excepted.

The water for the use of the hospital was obtained from a spring in the valley between the knoll on which the huts stand, and the huts occupied until lately by the marines, and at about 200 yards' distance from the former. In the valley are several springs of excellent water, but two only were in general use, one being principally frequented by the Turks, the other by the British soldiery, in the vicinity. The former of these springs is situated near the ruins of a house, and until the for mation of a large hospital by the Sardinians in the inmmediate neighbourhood, it was kept in tolerable condition; although the Turkish soldiers, on the whole, do not appear to be overcareful in keeping their sonrces of water-supply free from pol lution. No sooner, however, had a portion of the Sardinian hospital been erected, than the soldiery attached to it com menced to wash their dirty clothes on the slope of the bank above the spring, and close to it. The consequence was, that the ground about the spring was converted into mud, which trickled over and oozed through the imperfect stone-work, which, at some period or other, had been exected to protect and collect the water, and the spring was completely and, uncer the circumstances, irretrievably polluted. After the mischief had been done, an attempt was made to prevent further pollution of the water, and restore in some degree its purity, by digging a trench between the spring and the bank above it, but the measure failed; indeed, it was utterly inadequate to effect the desired object. During the months of August, September, and October, the water was always very muddy, and often offensive to the smell; and unless carefully filtered, it was unfit for use, particularly by invalids. It was, nevertheless, the only source from which the hospital had supplies, for the Turks were debarred drawing water from the springs used by the British and Sardinian troops.

Early in the spring, the colonel in command of the Marines, which corps was encamped on the heights, cansed a reservoir to be built in connexion with the spring from which his men drew their principal supply of water. This spring is near to that from which the water for the Turkish hospital was obtained; and until the period when indications of a failure of several of the springs on the heights occurred, it was open to all comers. When, however, there was reason to apprehend that a deficiency of water might happen, a sentinel was placed over the spring, the spring-head was covered in; none were allowed to draw water except from the reservoir, and the Turks were altogether excluded. The exclusion of the Turks was just; for of the few that visited this spring, some had been caught in various acts detrimental to the purity of the water-such as cleansing dirty vessels in the spring itself, occasioning an unnecessary formation of mud about it by scattering water carelessly in the vicinity, \&c.; and the spring principally frequented by them was equally good as that used by the British, and furnished, even to the last, an abundant supply of water. Had the Turkish authorities adopted the slightest precantionary measures, the pollution of that spring might with ease have been prevented. The carelessness of the Turkish soldier, as seen at the hospital, with respect to the purity of the water he drank, was something surprising. On the platean near the huts were several minor springs, from which ran constantly rills of the purest water; with care, any one of these might have been made to supply all that was requisite for the use of the patients; but although perfectly aware of this, both the authorities and the orderlies, and even those patients who were capable of getting about, preferred using the polluted water of the spring nearest to them-that, in fact, which was obtained with the least difficnlty. At one time, the authorities of the hospital, observing that two of the minor springs had, by the simple process of cleaning out and placing a sentry orer them, been made to do good service to the Sardinian hospital and to a battalion of Turkish infantry encamped on the plateau, attempted to find a spring which had existed within the angle of the plateau nearest the hospital. This spring had been hidden, and its course obliterated by the formation of the burial-ground of the Turkish troops on the heights. Notwithstanding this, one evening the Bey, the resident surgeons, the captain of the guard, and several workmen, proceeded to search for the lost water-course, and sundry holes were dug to this end within a few yards of the lower border of the general burial-ground. Luckily the search failed, and it was not renewed. Had it been conducted more towards the middle of the plateau, the result would probably have been different, as the water-course sought for permeated and traversed the burial-ground about its centre; for when graves were dug in that position they soon filled with water.

The water in the reservoir frequented by the Marines, and latterly by the Sardinians also, was not so pure as it might have been, for no measures had been taken to prevent muddy water during rain running from the slope of the hill above the reservoir into it. Moreover, the men were allowed to draw water from the portion of the reservoir nearest the spring, and in consequence some of the mud formed by water being spilled whilst lading out, ran into the reservoir and affected more or 
less the transparency of its contents. This might readily have been prevented, as the lower portion of the reservoir was elevated several feet above the slope of the hill, and arrangements could easily have been made for supplying the soldiers from the stream constantly flowing from the reservoir; and by conducting this stream also into tanks for washing, and troughs for the use of the horses, a great saving of time and trouble and of water could have been effected.

The Sardinian soldiers were a source of considerable trouble at first, as they proved to be worse than the Turks in their habits at the reservoir. They wished to commence washing near to it; and they attempted to cleanse their dirty cooking utensils in it. The Sardinian anthorities were requested to appoint a sentry to assist the British sentry in keeping the reservoir from pollution; and, in accordance with this request, a sergeant was sent daily to the reservoir until such time as the Sardinian soldiers frequenting it had learned more cleanly habits.

The burial-ground of the Turks was at the end of the valley, in the rear of the cliffs. It covered a considerable space of ground, as a single corpse only was interred in each grave. In order and neatness it contrasted most favourably with the Sardinian burial-ground established alongside of it. In the latter the graves were shallow, and each contained several corpses, and it not unfrequently happened that the covering of earth was so slight that a noisome odour exhaled from them.

It was rare to see amongst the patients, the guard, and the soldiers attached to the hospital, men whose physical powers were not fully developed. In this respect the matêricl of the Ottoman army seemed to exceed that of the British, French, or Sardinian armies. The Turkish soldier is, however, utterly ruined, in external appearance, by the abortion of a dress which he wears. Not only is the dress unsuited to his ideas and habits, but the material of which it is made is coarse and bad in the extreme, and the mode in which it is cut is a caricature of western fashions. Close-fitting trousers are inconsistent with his habit of sitting on the ground cross-legged, and with the predilections he has for pursuing many of his avocations upon his knees; and the state of dilapidation and deformity to which these articles of dress are soon reduced is truly deplorable. Moreover, as it has never been pointed out to him, or he cannot comprehend, that to keep dark cloth decent and clean a frequent use of the clothes-brush is necessary, and as he has no knowledge of the use of blacking for his shoes, and as the colour of the cloth of his dress is of a very fleeting character, his habiliments soon become shabby beyond deseription. But this is not all, for, in general, he persists in wearing the under clothing of the Osmanli-loose, thick cotton drawers and vests, and he delights in packing up his feet and legs in thick materials of some sort or other, and the uniform being pulled on over these, the man assumes an ungainly and lumberly appearance altogether peculiar. The men of those regiments which wear the slipper during the summer have straps of the same material as the trousers attached to this portion of their dress, not so much to keep the latter articles in an orthodox position as to retain the slipper in closer approximation to the foot. These additions to the dress are, however, inconsistent with the freedom of motion required for sitting cross-legged and kneeling (and the men shuffle along singularly well in their loose slippers); consequently it is most customary to see the straps disengaged from the slipper, and sticking out behind the heel in a most comical manner.

The Turkish soldier has a great propensity to wrap himself up. His mode of wrapping is, however, so clumsy that, when on a stormy day he may be doing duty as a sentry, he will look more like an animated bundle of old clothes than aught else. Imagine a man of somewhat squat form: a peaked and huge hood, of dark-brown coarse cloth, is drawn over his head and bound closely to it by a dirty white napkin. His body is enclosed in a large regulation great-coat, made of the same material as the hood. This coat is buttoned as tight as may be, but it is so filled up by some arrangement and accumulation of dress beneath, that on all sides it describes a perpendicular line from its upper to its lower extremity. The bayonet-sheath and shot-ponch project in the rear in a startling manner; and beneath the inferior edge of the coat are to be seen-first, the e ctremities of the regulation trowsers coming down to the ankles, and a pair of hnge straps sticking out behind; next, the extremities of the loose white drawers, with straps to correspond, the latter projecting also behind and above the heel Beneath these, and above the strong slipper, is seen some thick woollen material ensheathing the feet and leos, and bound to them with twine. Imagine a man thus attired easily sauntering about in a certain spot, and you may form some idea of the last sentry I saw, of the Turkish force in the Crimea, during a squally day. What an utter abomination the Turkish fez is, as a general head-dress, cannot be fully conceived until the Turkish army is seen.

The issue of clothing to each soldier is as follows:-

One uniform coat, one pair of uniform trousers, two pairs of white trousers, a light jacket for summer, two winter shirts, two summer shirts, two pairs of winter drawers, two pairs of summer drawers, two pairs of stockings, and one fez, every year; one pair of shoes every three months; and a great-coat every three years. A tent carpet is also issued to each man yearly.

The General Ration-List of the Ottoman army has a tolerably respectable look, but it is to be feared that, too often, its requirements are not carried out. It directs that to each soldier there shall be issued daily, of

Bread, three-fourths of an oke; rice, ninety-two drachms; butter, sixteen drachms; meat, ninety-two drachms; onions, nohud, and salt; soap, one drachm; charcoal, three hundred drachms; and wood, three hundred drachms.

To the occupants of each tent are also issued daily, one candle, and twenty-five drachms of olive oil, for cleaning arms, light, and other purposes. The soap, charcoal, and wood, are not issued to each soldier singly, but to parties of ten, who form a mess. To each mess is given a large, shallow, iron vessel, for cooking rice. Every tent, according to the regulations of the service, should contain not more than ten men, but the number is often increased to fifteen.

The conveyance of sick and wounded was effected by means of Tartar wagons, buffalo wagons, and pack-animals. The Tartar wagons (few in number) were, I believe, part of the spoil at Eupatoria. They were light, four-wheeled vehicles, covered in, and well adapted for sick conveyances. The buffalo wagons were vehicles of the rudest construction. They had four wheels, but the wheels rarely approximated to a circle, and each wheel generally differed from its fellow in diameter. The bottom was constructed of three or four pieces of rough, undressed timber; and the sides had a rude railing, inclining outwards.

On the evening when the Mamelon was assaulted and captured, (June 7 th,) a division of Turks having been moved into the trenches, to the right of the White-house Ravine, an order was received by the physician in charge of the hospital, directing him to send all the patients capable of being moved to Eupatoria, so that every preparation could be made for the reception of any wounded that might be sent from the front. A little before sunset, about twenty-five buffalo wagons, of the character described, slowly ascended the road to the hospital. At the same time, a movement was observed amongst the huts, and very soon about 250 patients were, with their bundles, placed on the ground in front of the huts. Many of these poor fellows were quite incapable of sitting up, unless supported. When the patients to be removed had all been got together, the process of packing them in the wagons commenced. But by this time it was dark, and the proceedings could not be well seen by the light of the lanterns used. It was near ten o'clock when a chorus of the dismallest creaks that ungreased axles could emit announced that the wagons had started with their freight of suffering. For several hours had the invalids, most of whom were suffering from diarrhoea and fever, been kept in the open air, on the ground; then came the rough and slow journey in the wagons; and after this would be the embarkation.

The most common mode of conveying the sick was by packanimals, the patient being placed astride an ordinary packsaddle. I have frequently seen poor fellows fall off exhausted, and lie by the road-side upwards of an hour before they could again proceed. I have seen instances of this kind occur within a hundred and fifty yards of the hospital, and no assistance has been given, but the invalid has been allowed to lie on the ground, the leader of the pack-animal sitting by him, until such time as he was able to overcome the remaining distance.

About twenty mules, with seats for the sick, after the French fashion, were, during the past campaign, attached to the army, and they did good service, and it is to be hoped that this inkling of an improvement may not be illusory.

Of the general health of the Ottoman force at Balaklava, and of the diseases and mortality prevalent amongst the soldiers, I have no trustworthy information. The services of the British medical staff attached to that force were confined to surgical cases, and of these but very few occurred.

Sinope, November, 185̃. 